\title{
On the Makings of British Cultural Mode and Its Modern Significance for Eastern Reference
}

\author{
Guoqiang Cui \\ PhD candidate; Full-time lecturer of School of Foreign Languages, Jilin University of Finance and \\ Economics, Jingyue Street, Jingyue District, Changchun, Jilin Province, P.R.China, 130117
}

cuiguoqiang123@126.com

Keywords: Cultural Mode; Conflicts; Fusions; Eastern Reference

\begin{abstract}
As a hybrid of precious tradition and practical transformation, British culture has undergone a glorious path, which is now acknowledged as distinctive "British mode". Though it has been struggling between conflicts and fusions, the results have always turned out to be positive and moving the nation forward. The Eastern civilization shares the same length of history and prosperity, but what should be learned from British cultural mode? It's a question worth reflection.
\end{abstract}

\section{Introductory Remarks - the Makings of Today's British Society}

As the famous American maritime historian Alfred Thayer Marhan claimed, "If a country is located in that way (surrounded by sea), there is neither the need for a defense in land, nor the impulse of an expansion in land; therefore, it can develop without disruptions. On top of that, it effectively controls the vital communication line---The English Channel". [1] In addition to the blessed geographical advantage, the British is also largely attributed to domestic wealth accumulation, mercantile system and their high emphasis on colonization. Different from the patterns of colonization of Spain and Portugal, the British colonization concept converted from "money-preference" to "trade-preference", which, in other words, means the most direct intention of foreign expansion was to open wider trade routes and lines, thus to balance its economy.

Wonderfully reflecting John J. Mearsheimer in The Tragedy of Great Power Politics, Britain plays a role of offshore balancer, [2] distracting other great powers while strengthening itself in a geographically safe manner. As for foreign policy, it carries on a "continental balance strategy", a state of detachment for most of times and fights against the extreme power in urgency. In addition, Britain is famous for its recently stressed cultural diplomacy strategy, aiming at enhancing the country's soft power and international influence. [3] However, the decisive factor for today's British success is its stable internal politics, which is determined by its matured culture---a hybrid of tradition and modernism, as well a hybrid of conflict and fusion. The conflicts break out between the royal power and the civil rights, equality and wealth inequality, conservatism and radicalism, rationalism and religion. Surprisingly, they end up as fusions and compromises. It is just in this way British society becomes what it is today.

\section{The Royal Power V.S. The Civil Rights}

As a representative monarchy constitutional regime in the globe, the modern system originates from the country's feudal past. When William I led the nobles to conquer England, he allocated the land into small pieces in case of any one of them developed into a super power. They all swore allegiance to the King. But the nobles soon found they had to unite together for "legal rights". Under the banner of "rights", they dared take up weapons to challenge the authority of the King; this is where "liberty" began in Britain. From John of Salisbury we find they later believed that law could be the most powerful restraint to the King. [4] Eventually, the less capable King John was obliged to sign the Magna Carta with the nobles. Magna Carta confined the power of the King, gave certain rights to the 
church and the aristocrats. It was the first step for England to establish Constitutional monarchy. For the fist time, the Magna Carta provided individuals like civilians with their own rights. It was from then on that they learned their self-existence according to the laws.

As the conflicts between the King and the nobles never stopped, a new solution of disputes was badly needed. Provisions of Oxford firstly turned up on historical stage, according to which the national affairs final decision went to the twelve-member Parliament. [5] Although the victory result of 1265 rebellion did not last long, it laid a solid foundation for Parliament system; especially the middle class (including the Equites and urban citizens) were enrolled by the Parliament. This made the idea of "liberal rights" spread among the whole population. The 1258 Provisions had a significant effect upon the development of the English Common Law system. In and after the reign of Henry II the number of available writs (recognized causes for legal action in the common law courts in London) had grown. This expansion of jurisdiction by the royal courts aroused so much resentment that the 1258 Provisions of Oxford provided that no further expansion of the writ system would be allowed.

The monarchy closes the door of separation; the Parliament is the spokesman for the public. The combination of the monarchy and Parliament by law makes the system a great success. Voices of "divine royal power" and "divine civil rights" fuse into a Glorious Revolution. All the parties and classes discovered a moderate path for permanent sustainability.

\section{Call for Wealth V.S. Call for Equality}

It cannot be denied that except for technological and economic reasons, there are psychological and cultural factors for Industrial Revolution as well. Obviously, the Industrial Revolution was not a carefully planned event, then how came the motives for it? The answer seems to be simple: "greedy" people and "proper" society. The former refers to people longing for wealth and better life, the latter refers to a society which does not restrain the greedy pursuit, but guides the pursuit onto a healthy path (as mentioned above, varied from that of Spain, Portugal and France).

Above all, Britain had got favorable political environment for capitalism. Take the cities for example, the urban land can be bought and sold; the King could not tax beyond fixed amount; they even owned personnel and legislation independence. Besides, the Britain had formed ideal social class division, evident but flexible social classes, including the nobles, middle class and the labor class. By and by, the spirit of reasonable seeking for profits emerged among the rising middle class, who were mainly made up of craftsmen, merchants, employers, millers and urban dwellers. The pursuit for wealth among the middle class would easily turn to mighty momentum of reasonable seeking for profits. Another valuable distinction in Britain nobles was they shared political privileges, but had no economic privileges. They paid for the same amount of tax, which made them weigh quite much on economic activities; even the King George III was self-proclaimed as "Farmer George". [6]

During the early period of Industrial Revolution, the distribution of social wealth was quite unequal, which was featured by the labor workers' starving to death. From the early contemplation of John Wycliffe, to the failure of peasants' uprising under John Ball's "democracy and public property", to Gerrard Winstanley and the Diggers movement, [7] to the earliest complete theoretic system for equality by Thomas Paine, and practice of contemporaneous Thomas Spencer, to the communist exploration of Thomas Irwin, until the foundation of Labor Party in 1900. All these pave solid way for the building of a "welfare nation". Again this time, between the conflicts of wealth and equality, Britain fuses into an equal welfare society balancing economic prosperity.

\section{Conservatism V.S. Radicalism}

In every political contest in a Constitutional system the names of Conservatism and Radicalism will be applied to the opposing policies, while the history of such governments shows that the policy which truly conserves the principle and spirit of a free system is that which is called Radicalism. 
Conservatives typically see Richard Hooker as the founding father of conservatism, with Edmund Burke representative. He accepted the liberal ideals of private property and the economics of Adam Smith, but thought that economics should remain subordinate to the conservative social ethic, that capitalism should be subordinate to the medieval social tradition and that the business class should be subordinate to aristocracy. He insisted on standards of honor derived from the medieval aristocratic tradition, and saw the aristocracy as the nation's natural leaders. That meant limits on the powers of the Crown, since he found the institutions of Parliament to be better informed than commissions appointed by the executive. He favored an established church, but allowed for a degree of religious toleration. Burke justified the social order on the basis of tradition: tradition represented the wisdom of the species and he valued community and social harmony over social reforms. [8] Burke was a leading theorist in his day, finding extreme idealism an endangerment to broader liberties, and rejecting abstract reason as an unsound guide for political theory.

Judging from its root, radicalism seems to ask for a complete change of the present institutions. Unlike the conservatism, radicalism upholds the law of nature, seeing is the social basis. It inevitably involves getting back to the past. The earliest radicals were mostly communists, they dreamed of a society without harm caused by private property and without inequality. Though the later radicals give up part of the dream, they would like to measure everything in real life by equality and justice, thus reaching a conclusion of reform. The Independents wanted a victory over the throne; the Equals wanted a thorough democracy, while the Diggers thought the political freedom was based on economic freedom. It seemed difficult for them to find a well-accepted meeting point.

1832 marked a turning point in the history of conservatism and radicalism. Due to the nationwide chaos from 1830, the Parliament received big reform, which turned out to be great success. The conservatives realized the necessity for a change, while the radicals understood the limits of reality. Once more, the conflicts between conservatism and radicalism fused into a gradual development mode, setting a good example for their future disputes.

\section{Religion V.S. Rationalism}

In medieval times, the Church developed into a mighty and all-embracing power. As for freedom and choice, people generally believed they mainly belong to the God, then to the angels before to the humans. The God would never do anything wrong. The human power seemed to be quite fragile in front of God. Though the theory of divine rights dominated people's mental world was helpful for a relatively stable social order, it serveley hindered the society from moving forward.

As the stable social order facilitated free trade, free trade helped the wealth accumulation; wealth accumulation ased for bigger market and higher lever science and technology, the old social framework could not satisfy the demand any more. Then the reform began from astronomy, soon it spread to naval navigation and science of mechanism. People started to value money, empirical knowledge and hardwork, to long for love, wealth and hapiness, this was the budding period of rationalism.

Walking out of the medieval times, John Wycliffe became the first challenger of old ideas of religion, proposing a rational innovation. St. Thomas More's Utopia also contributed more to people's mental progress. "Who enjoys a higher position? Religion or rationalism?" when the deeply anxious question prevailed, Francis Bacon clearly pointed out that "Knowledge is power" and "Human experience is the source of all knowledge".[9] Hume's skepticism and Newton's discoveries in physics had already shaken previous public belief in God, then Darwin's evolutionism gave it a heavy blow. The theory of evolution refers to the philosophical worldview or belief in theories that material complexity has developed through purely natural processes. More specifically, it is the advocacy of, or belief in Darwinian mechanisms as being responsible for all life on earth. It was derived from atheistic philosophy, and is the key evidence used by atheists to explain the existence of humans independent of a deity. In this context evolution plays a vital role in the fulfillment of the 
belief system of the religion known as secular humanism. An Evolutionist is a proponent of such theory. Theories of change have been developed across several fields of study. Evolutionists embrace evolution through a belief system, not because it has become a proven scientific fact.

Thereafter, though the religious strength continues and the clergymen went on declaring humans were creatures of God, the old dispute had lost sense. The more practical question was how to position religion in a rational world.

In this round of conflict, the Britain society fused into a theistic society according greater importance to rationalism. People adopt a rational manner to cope with objective world and practical matters, and use a religious manner to understand their mental world.

\section{British Mode's Modern Significance for Eastern Reference}

To sum up, conflicts and fusions have filled the whole British history. The British society have been strugging between tradition and transformation.[10] This has formed a unique British cultural mode, which further influences and pushes the society moving forward to a better way. Some people protect the tradition, some seek for reforms. When the conservatives sense the need for a change, the accept the transformation, otherwise, the remain the situation in case it developed towards a wrong or a direction full of uncertainties and risks. This mode imposes greatly on the country's economy, politics, commerce, social life and religion.

The British are the most gentlemanly nation. Specifically, they set fair and reasonable rules for competition, no matter in commercial, political and athletic aspects. They can control their emotions and behave rationally, not to involve in personal privacy, and keep clam in political affairs. They also display strong "John Bull" spirit, never give up halfway.

Compared with class mobility, the social stability is quite crucial for a country's prosperity. The nobles are always willing to defend their royal image, eager to become moral models. They are independent, brave, educated and have a strong sense of social responsibilities. It is tough for a nouveau riche to promote to a noble member. In the meanwhile, the middle class base their ethical code upon work. They want to succeed through hard work and tend to be economical and do much work by themselves.

As Baron de Montesquieu noted, the British walked in front of the other nations in piety, commerce and freedom. These virtues are rocket propellants for rationalism, industrialism and eternity. As two varied civilizations, the East and the West have been imposing influence on each other, learning from each other and more importantly, benefiting from each other.

\section{References}

[1] Alfred Thayer Marhan. Sea Power Theory, with a Chinese translated version by YI Bing, Beijing: Tongxin Press, 2012.

[2] John J. Mearsheimer. The Tragedy of Great Power Politics, with a Chinese translated version by Yigui, Wang and Xiaosong Tang, Shanghai: Shanghai Century Publishing Group, 2003.

[3] Wentao, Hu. "Britain Cultural Diplomacy: A Successful Path to Enhancing the Country's Soft Power" [J]. Pacific Journal, 2010 (9).

[4] Chengdan, Qian, Xiaolv, Chen. Between Tradition and Transformation: A Dating back of British Cultural Mode, Nanjing: Jiangsu People's Press, 2010.

[5] Maitland. The Constitutional History of England, with a Chinese translated version by Honghai, Li, Beijing: China University of Political Science and Law Press, 2010.

[6] Mengyin, Jiang. A British History, Nanjing: Nanjing University Press, 1964. 
[7] Guodong, Ren. Gerrard Winstanley Analects (trans.), Beijing: Commercial Press, 1965.

[8] Auerbach. The Conservative Illusion, (1959), p. 41

[9] Baokui, Xu. Novum Organum (trans.), Beijing: Commercial Press, 1984.

[10] Riyun, Cong. Western Political and Cultural Traditions, Haerbin: Heilongjiang People's Press, 2002. 